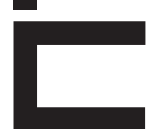

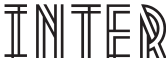

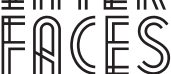

CIENTÍFICAS

HUMANASE SOCIAIS

ISSN IMPRESSO 2316-333X

ISSN ELETRÔNICO 2316-3828

\title{
CIDADANIA POLÍTICA E PARTICIPAÇÃO ELEITORAL NO BRASIL EM PERSPECTIVA HISTÓRICA
}

Lorena Madruga Monteiro ${ }^{1}$
Daniela do Carmo Kabengele ${ }^{2}$

\section{RESUMO}

0 artigo procura demonstrar, por meio da análise histórica das regras eleitorais no Brasil, quem podia exercer a cidadania e que sociedade política originava-se desses arranjos representativos. Seguindo a cronologia histórica de aquisição de Direitos no Brasil, o texto abrange desde reflexões sobre a formação da sociedade política no período imperial até a atual configuração da política representativa brasileira.

\section{PALAVRAS-CHAVE}

Regras Eleitorais. Cidadania. Representação Política. 


\section{ABSTRACT}

Through historical analysis, the article attempts to show the electoral rules in Brazil: who was entitled to exercises citizenship and which political society was originated from these representative arrangements. Following closely the historical chronology of acquisition of Rights in Brazil, the analysis ranges from reflections of the formation of political society in the imperial period to the current configuration of the Brazilian representative politics.

\section{KEY WORDS}

Electoral Rules. Citizenship. Political Representation.

\section{RESUMEN}

El artículo trata de demostrar, a través de unanálisis histórico de lasreglaselectoralesen Brasil, que podríaejercerlaciudadanía y lasociedad política de tallo representante de estos arreglos. Siguiendolacronología histórica de laadquisición de derechosenel Brasil, el texto abarca desde reflexiones sobre laformación de lasociedad política enla época imperial a laconfiguraciónactual de la política de representaciónen Brasil.

\section{PALABRAS CLAVE}

Reglas Electorales. Cidadania. Representación.

\section{INTRODUÇ̧̃̃O}

Diferentemente da cronologia normativa da aquisição de direitos preconizada porT. H. Marshall, em relação aos países europeus, na qual inicialmente formaram-se os direitos civis, após os políticos e por fim os sociais, no Brasil os direitos políticos vieram em primeiro lugar. Assim, como, a aquisição dos direitos - civis, políticos, e sociais - não foi consequência de lutas populares, mas sim da ação do Estado. Tais especificidades da formação política e social brasilei$\mathrm{ra}$ - como a defasagem entre direitos legais e aqueles realmente exercidos, ou o fato de ter instaurado os direitos políticos, no período imperial, numa sociedade que negava direitos fundamentais a escravos e homens livres, ou mesmo a questão dos direitos sociais terem sido implantados por regimes que restringiam os direitos políticos - decorrem, em parte, da transpo- sição da cultura política ibérica, baseada nas relações paternalistas, clientelistas. (SAES, 2001).

Embora a discussão ampla sobre a cidadania política no Brasil seja instigante e tema de vários estudos (CARVALHO, 1997; 2002; COSTA, 1981; SAES, 2001), nosso objetivo nesse artigo é demonstrar, por meio da análise histórica das regras eleitorais no Brasil, quem podia exercer sua cidadania e que sociedade política originava-se desses arranjos representativos. Com este objetivo dividiu-se o artigo em seis subitens, seguindo a cronologia histórica de aquisição de Direitos no Brasil. Abrange, desse modo, desde reflexões sobre a formação da sociedade política no período imperial, até a atual configuração da política representativa brasileira 


\section{ELEITORES E ELEGIVEIS NO PERÍODO IMPERIAL: DAS ELEIÇÕES PAROQUIAIS À UMA SOCIEDADE POLIITICA REDUZIDA.}

Durante o período Imperial (1822-1889) implantaram-se as primeiras regras eleitorais para pleitos presididos no Brasil. Anteriormente, no período colonial, as eleições, de caráter local, eram realizadas conforme o Código das Ordenações do Reino. A Constituição imperial de 1824 pode ser considerada o marco originário da aquisição dos Direitos políticos no Brasil. No entanto, apresenta especificidades em seu formato que devem ser destacadas.

Uma delas é que a seleção do eleitor final para os pleitos referentes à escolha para o Senado, para a Câmara dos Deputados e para as Assembleias Provinciais dava-se em dois níveis (ou graus como chamavam à época) até 1880 . Esse modelo de eleições indireta começava na contagem das moradias (fogos) realizada pelos Párocos de cada freguesia que colavam a relação na porta da Igreja até o dia determinado para a realização das eleições. Portanto, a Paróquia (freguesia) era o território aonde ocorria à vida eleitoral. Nela que se realizava a qualificação dos eleitores, a partir delas que se definiam o número dos eleitores que elegiam os deputados e senadores, e nelas que ocorriam as eleições para os eleitores de paróquia e para os provinciais.

No dia das eleições, depois da missa (no início do Império, depois esse ritual foi abolido), podiam escolher os eleitores de paróquia aqueles moradores da freguesia que fossem maiores de 25 anos e comprovassem renda anual igual ou superior à 100 mil réis. Deste processo estavam excluídos:

[...] Os menores de 25 anos, nos quais não se compreendem os casados, e os Oficiais Militares, que forem maiores de vinte e um anos, os bacharéis formados, e clérigos de ordens sacras; II- Os filhos -família que estiverem na companhia de seus pais, salvo se servirem Ofícios Públicos; III- Os criados de servir, em cuja classe não entram os guarda-livros, e primeiros caixeiros das casas de comércio, os criados da Casa Imperial, que não forem de galão branco, e os administradores das fazendas rurais e fábricas; IV- Religiosos e quaisquer, que vivam em comunidade claustral; V- Os que não tiverem renda mínima líquida anual de cem mil réis por bens de raiz, indústria, comércio, ou emprego (FERREIRA, 2006, p. 90)

Logo, a seleção dos eleitores era pautada pelo critério econômico e pela maioridade de 25. Esse último aspecto não se aplicava aos Oficiais Militares que podiam votar desde os 21 anos, assim como para os Clérigos e Bacharéis que votavam independente da sua idade. Embora não fosse proibido explicitamente, mas o próprio requisito da renda os excluía, mulheres, escravos não tinham direito ao voto. (NICOLAU, 2004). Já os analfabetos tinham direito ao voto, mas como de 1824 a 1842, exigia-se que a cédula fosse assinada, 0 voto foi limitado. No entanto, os analfabetos, entre 1942 e 1881, foram eleitores e elegíveis, como exemplifica Jairo Nicolau (2004, p. 11):

\begin{abstract}
Um levantamento da lista de votantes de 1876, feito em oito paróquias da cidade do Rio de Janeiro, revela um contingente significativo de votantes que não sabiam ler e escrever: um em cada quatro. Nas paróquias rurais, como Guaratiba e Jacarepaguá, as analfabetos ultrapassavam 50\%."
\end{abstract}

A possibilidade do voto do analfabeto encontra-se no primeiro título de eleitor (à época título de qualificação), de 1875, o qual, entre informações como nome, idade, estado civil, profissão, renda, domicílio, elegibilidade, existia um item a qual a pessoa declarava-se alfabetizado ou não (NICOLAU, 2004). Portanto, todos esses requisitos determinavam à elegibilidade dos “cidadãos".

Em relação à elegibilidade outro aspecto é interessante: o aspecto partidário só aparece na última fase das eleições, quando os eleitores provinciais escolhem os deputados e senadores da sua preferência. Desse modo, ao menos formalmente, 
os Partidos (Liberal e Conservador) não estavam presente nos pleitos para os eleitores paroquiais e provinciais, uma vez que a massa de cidadãos aptos ao voto pelas paróquias chegava no dia da votação com uma listagem com os nomes e as respectivas profissões daqueles que votariam como eleitores paroquiais. No entanto, como os Partidos organizavam as eleições conforme o interesse daquele que ocupava o gabinete do Imperador de produzir maiorias legislativas, ocorriam muitos processos fraudulentos.

O cálculo de quantos nomes podia ser citado como possíveis eleitores baseavam-se no número da população apta ao voto em cada paróquia, que, de cada 100, resultava num eleitor paroquial. Dessa forma, o número de nomes relacionados pelos cidadãos ativos variava conforme o número que a paróquia podia eleger como eleitores da freguesia. A contagem final se dava por maioria simples, ou seja, elegiam-se os mais votados até o preenchimento das vagas da paróquia.

Todos esses eleitores de paróquia, eleitos nas variadas freguesias da província, constituíam os colégios eleitorais. A votação em segundo grau ocorria 15 dias após a paroquial, e todos os diplomados como eleitores provinciais reuniam-se nas chamadas cabeças de distritos, nas cidades. Nessa votação esses eleitores podiam listar tantos nomes quanto fossem o número de deputados da província na Câmara. No entanto, ao contrário da votação em primeiro grau que os cidadãos aptos ao voto assinavam suas listas de candidatos, os eleitores de paróquia votavam por escrutínio secreto e através de cédulas. A apuração final era realizada na Câmara Municipal da Capital, e elegiam-se deputados àqueles que foram mais votados em toda província. Já o número de Senadores eleitos pelos eleitores provinciais variava conforme o número de deputados de cada província, uma vez que correspondiam à metade dos deputados eleitos, e o Imperador decidia, dentre os mais votados, os três eleitos para um mandato vitalício.
Só eram elegíveis como deputados aqueles que tinham renda anual de 400 mil réis; entre os Senadores, aqueles com renda anual de 800 mil réis, e maioridade de 40 anos. Portanto, o critério de quem detinha o direito ao voto, e aqueles de elegibilidade, produziram uma sociedade política extremamente reduzida, que, embora não existam estatísticas gerais confiáveis para o período, pode-se estimar representar entre $1 \%$ a $10 \%$ da população até 1880 . Além disso, o controle das eleições pelo Partido que ocupava o gabinete no sistema monárquico, gerava, ao produzir suas maiorias legislativas, pouca alternância de poder e o debate sobre a representação das minorias, o que pautou as constantes alterações nas legislações eleitorais (por exemplo, o modelo de representação por círculos), sem, contudo, produzir resultados satisfatórios.

Em relação ao eleitorado e a representação política durante o período imperial ainda cabe destacar a legislação de 1881, a lei Saraiva (Lei do Censo). A partir dessa lei foi abolido o voto indireto, e assim todos os candidatos a mandatos políticos (Senadores, Deputados Gerais e provinciais) eram escolhidos diretamente por todos os eleitores alistados e em conformidade com a lei.

0 alistamento eleitoral passou a ser de iniciativa do "cidadão", preparado pelo Juiz municipal e registrado pelos juízes das Comarcas, deixando, assim, de ser ex-officio, quando eram organizadas pelos padres e depois pelas juntas de alistamento. 0 analfabeto passou a ter direito ao voto garantido por lei, pois, caso não pudesse assinar, era permitido que indicasse outro para fazê-lo. No entanto, mantendo o requisito das leis anteriores, só eram eleitores aqueles maiores de 25 anos se solteiros, acima de 21 anos se casados e oficiais militares, qualquer idade para Clérigos e Bacharéis que comprovassem renda anual de 200 mil réis. Ademais, era necessário ao menos ao ano de domicílio na localidade.

Já em relação á elegibilidade a lei aumentava o critério de renda anual para candidatos a Senadores, 
que passava a ser de 1600 mil réis, e para os candidatos a deputados ficava em torno de 800 mil réis, além de incluir para os candidatos para as assembléias provinciais o requisito de mais de dois anos de residência na província. 0 que de fato aparece de novo nesta lei, além do voto secreto, e do alistamento prévio, foi uma relação extensa de incompatibilidade de vários cargos com o exercício do mandato político, tais como:

Os diretores gerais do tesouro nacional e os diretores das Secretarias de Estado; os presidentes de província (eram nomeados pelo Imperador), os Bispos em suas Dioceses, os comandantes de armas, os generais -em -chefe de terra e mar, os chefes de estações navais, os capitães de porta, os inspetores ou diretores de arsenais, os inspetores de corpos de Exército, os comandantes de corpos, militares ou de polícia, os secretários de governo provincial e os secretários de polícia da corte e das províncias, os inspetores de tesouraria de fazenda gerais ou provinciais, e os chefes de outras repartições de arrecadação, o diretor geral e os administradores dos Correios, inspetores ou diretores de instrução pública, os lentes e diretores de faculdades ou outros estabelecimentos de instrução superior, os inspetores das alfândegas, os desembargadores, os juízes de direito, os juízes municipais ou de órfãos e seus substitutos, os chefes de polícia, os promotores públicos, os curadores gerais de órfãos, os desembar- gadores de relações eclesiásticas, os vigários capitulares, os governadores de bispado, os vigários gerais [...] (FERREIRA, 2006, p. 233)

Embora não se analise em profundidade, a questão da representação das minorias esteve presente nessa legislação, tanto que se adotou distribuição de cadeiras para as câmaras por distrito de um representante. 0 que é importante destacar é que o eleitorado reduziu-se após a implementação da lei Saraiva. Conforme Jairo Nicolau (2004), isso ocorreu, em parte, pelos critérios mais rigorosos de comprovação de renda, a exigência de saber ler e escrever para alistar-se, e pela própria iniciativa do eleitor em qualificar-se, não sendo feita ex-oficcio. No entanto, em relação ao eleitorado de segundo grau ocorreu um incremento de votantes habilitados. Logo, tal incremento refere-se aqueles cidadãos com escolaridade e melhores situados economicamente.

Conforme a obra clássica de José Murilo de Carvalho o resultado desse arranjo representativo foi que a elite política imperial representava uma ilha de letrados num mar de analfabetos, como ilustra quadro abaixo em relação aos Senadores:

Quadro I: Nível escolar dos Senadores por período (1822-1889)

\begin{tabular}{|c|c|c|c|c|c|c|}
\hline Educação/ Período & $1822-31$ & $1831-40$ & $1840-53$ & $1853-71$ & $1871-89$ & Total \\
\hline C/ educação superior & $81,81 \%$ & $73,34 \%$ & $57,90 \%$ & $80,00 \%$ & $80,77 \%$ & $76,11 \%$ \\
\hline Sem educação Superior & $15,15 \%$ & $26,66 \%$ & $31,58 \%$ & $20,00 \%$ & $19,23 \%$ & $21,24 \%$ \\
\hline Sem informação & $3,03 \%$ & & $10,52 \%$ & & & 2,62 \\
\hline Total & $100 \%$ & $100 \%$ & $100 \%$ & $100 \%$ & $100 \%$ & $100 \%$ \\
\hline
\end{tabular}

Fonte: CARVALHO (2006, p. 78) 
A grosso modo, dado os requisitos de elegibilidade (para os cargos de eleição direta e também para os nomeados), pode-se dizer que a elite política era composta daqueles indivíduos abastados que puderam investir na sua formação superior na Universidade de Coimbra. Ou seja, uma elite econômica cuja formação escolar, em especial a jurídica, produziu uma homogeneidade ideológica, que teve relação com a formação e estrutura do Estado imperial no Brasil (CARVALHO, 2006). Entretanto, a essa primeira geração de Coimbra sucedeu-se a geração brasileira, oriunda, de um lado das Escolas técnicas e Militares, de formação técnica e positivista, e por outro das Faculdades de Direito de São Paulo e Recife, de formação distinta, a primeira mais ligada à esfera da política, e a segunda a divulgação teórico-doutrinária, mas que seguiam a formação da Universidade de Coimbra.

Portanto, essa geração brasileira; sejam aqueles advindos das escolas técnicas militares, que se opunham à formação jurídica e eclética da elite civil, sejam aqueles da Faculdade de Direito de Recife, de orientação mais intelectualista, ou aqueles da Faculdade de Direito de São Paulo, que representavam, nas palavras de Sérgio Adorno (1998), o "mandarinato imperial” de bacharéis; que gerou, através de disputas intra-elites, a república no Brasil. Logo, essa geração representava muito menos da população alfabetizada no Brasil durante o período imperial, conforme quadro abaixo:

Quadro II: População alfabetizada (1872-1890)

\begin{tabular}{|l|l|l|}
\hline & 1872 & 1890 \\
\hline Homens & $23,43 \%$ & $19,14 \%$ \\
\hline Mulheres & $13,43 \%$ & $10,35 \%$ \\
\hline
\end{tabular}

Fonte: CARVALHO (2006, p. 80)

Esta luta intraelite, de forma geral, a qual Elisa Reis (1998) explora em sua reflexão sobre a construção do Estado brasileiro, dizia respeito à elite oligárquica (logo, os bacharéis brasileiros, com algumas exceções) que defendiam o "liberalismo", ou seja, um governo descentralizado que garantisse a autonomia das unidades subnacionais, o qual o Estado seria o protetor dos bens, propriedades e direitos privados, interferindo o menos possível na economia interna das regiões; e entre aqueles de orientação positivista, representados pelos militares, que advogavam em favor de um Estado centralizador.

\section{ELEITORES E ELEGIVEIS NA REPÚBLICA VELHA: DOMINACÃ̃O POLÍTICA, FRAUDES E BAIXO COMPARECIMENTO ELEITORAL}

A República foi implantada, provisoriamente, em 1889, após o golpe de Estado dos militares, liderados pelo Marechal Deodoro da Fonseca, que depôs o Imperador. Inicialmente, a ideia do governo republicano foi abolir todos os privilégios do Império, em especial a exigência de renda para ser eleitor e candidato. No entanto, ao instituir o direito ao voto a todos brasileiros que soubessem ler e escrever excluiu o voto dos analfabetos, regra que perduraria por cerca cem anos.

Mesmo assim, no início desse período, aqueles indivíduos, mesmo analfabetos, qualificados pela lei anterior, podiam exercer o voto. As principais mudanças para a qualificação para as eleições constituintes referem à redução da idade de 25 para 21 anos (exceto para os casados, os oficiais militares, bacharéis, doutores e clérigo que o exercício do voto independia da idade) e a forma de alistamento. 
A qualificação eleitoral estava ao encargo de comissões distritais, compostas de um Juiz de Paz, um subdelegado do município (paróquia), e um eleitor, residente na localidade, que fosse nomeado pelo presidente da Câmara. Neste primeiro momento, o eleitor deveria provar ser alfabetizado, e residência de mais de seis meses no distrito. Após, a requisição passava por uma segunda comissão, que podia eliminar eleitores aprovados na primeira, composta pelo Juiz municipal, pelo presidente da câmara e pelo delegado de polícia. Portanto, o alistamento eleitoral estava ao encargo de cargos dependentes do governo.

Com a constituição de 1891 as regras em relação ao eleitorado, a elegibilidade e a representação política consolidam-se. Nela se reitera o direito ao voto aos maiores de 21 anos, alfabetizados e detalham-se aqueles aos quais não podem votar, tais como analfabetos, mendigos, os praças de pré, a exceção dos alunos das escolas militares de ensino superior; os religiosos das ordens monásticas, congregações, comunidades, todos os seguiam voto de obediência em detrimento de sua vontade individual, e os cidadãos qualificados como não elegíveis no alistamento.

Quanto à elegibilidade podiam candidatar-se ao Congresso Nacional (Câmara dos Deputados e Senado) aqueles que tivessem direitos de cidadão brasileiro e fossem eleitores, e tivessem mais de quatro anos de cidadania brasileira para a Câmara, e mais de seis para o Senado, além da maioridade de 35 anos, norma que também se aplica aos candidatos a Presidente e vice da república. A incompatibilidade de cargos com o exercício do mandato público de Senador e Deputados reduziu-se em relação à lei Saraiva, e aplicava-se apenas para aqueles que exerciam funções de ministros do presidente da república e os diretores de suas secretarias e do tesouro nacional; os governadores ou presidentes e seus vices; os ajudantes generais do Exército e da força armada; os comandantes do distrito militar no respectivo distrito, os funcionários militares na ativa; as autoridades policiais, membros do poder judiciário; os magistrados (FERREIRA, 2004)
A partir da regulamentação de 1892 a qualificação para o alistamento eleitoral passou por um processo de politização, especialmente nos municípios, uma vez que "as facções majoritárias na política local passaram a controlar o processo de alistamento, que deu margem a toda sorte de fraudes e manipulações para facilitar a inclusão de correligionários e a exclusão dos adversários" (NICOLAU, 2004, p. 29). Tais práticas não foram eliminadas com a regulamentação de 1904, a qual mudou a comissão de alistamento, que passou a ser composta de um Juiz de Direito, dois indivíduos que fossem os maiores contribuintes de imposto predial, os dois maiores contribuintes sobre a propriedade rural, e três cidadãos indicados pelo governo municipal. Mesmo quando a qualificação dos eleitores para as eleições federais voltou a ser encargo do poder do judiciário, em 1916, e o alistamento requisitava firma reconhecida, comprovação da idade, de renda, de residência, e de escolaridade; as práticas fraudulentas, especialmente advindas da política municipal, não foram abolidas.

Dentre tais práticas de falsificação eleitoral as mais conhecidas foram o Bico de Pena e a degola. A primeira, descrita por Vitor Nunes Leal, em sua obra clássica, coronelismo, enxada e voto, refere-se à adulteração das atas da mesa eleitoral, onde registravam com seus bicos de penas nomes de pessoas mortas, ausentes, inexistentes; ou seja, forjavam-se um contingente eleitoral em prol da facção política que representavam. Já a decola, refere-se à atividade da Comissão Verificadora dos Poderes, composta por uma comissão de deputados incumbidos da organização da lista dos deputados eleitos legítimos para a próxima legislatura, que, quando composta dos grupos governistas, vetava (ou degolava na linguagem da época) e não reconhecia a diplomação dos deputados oposicionistas eleitos.

Destaca-se que o alistamento eleitoral e o voto eram facultativos e os cargos políticos mais importantes eram preenchidos por meio de eleições. 0 presidente e vice eram eleitos por maioria absoluta de votos, em pleito independente, os Deputados e Senadores, por maioria simples, e no caso das eleições para o Sena- 
do, cada Estado elegia três, que a cada três anos 1/3 era renovado. A particularidade desse sistema referia-se a autonomia política de cada Estado, uma vez que cada um organizava a seu modo o processo eleitoral de escolha dos governadores e das Assembleias legislativas. Desse modo, havia Estados que os prefeitos eram indicados pelo governador, em alguns o presidente da câmara assumia as funções do executivo, e em outros o chefe do Estado era eleito (NICOLAU, 2004).

Interessante, também, que o material eleitoral não era confeccionado apenas pelas mesas eleitorais, e as candidaturas não eram, necessariamente, atreladas aos partidos políticos. 0 eleitor votava em cada célula diferente para cada cargo, e as adquiria tanto no local das eleições, como por meio dos recortes das cédulas dos candidatos publicados nos jornais, assim como entre os cabos eleitorais. Além disso, os eleitores podiam votar em quem quisessem, uma vez que não existia registro prévio dos candidatos, nem obrigação de que fossem vinculados a Partidos Políticos para concorrer.

No entanto, tal liberdade de voto era reduzida e ilusória, uma vez que, mesmo que a lei eleitoral de 1904 mantivesse o voto secreto, introduziu o voto a descoberto, prática que já existia no Rio Grande do Sul desde 1897. Desse modo, os eleitores assinavam e votavam em duas cédulas que após serem datadas e rubricadas pelos mesários, depositava-se uma na urna, e a outra ficava com o eleitor. Assim, as lideranças locais (coronéis) tinham na cédula do eleitor um instrumento de comprovação do voto dado.

De modo geral, o processo eleitoral durante as primeiras décadas da república caracterizou-se pelo baixo comparecimento eleitoral (NICOLAU, 2004). Estima-se que entre 1912 a 1930 a participação eleitoral não passou de $5 \%$ da população em geral. Isto esteve relacionado à exclusão do voto das mulheres e dos analfabetos, e ao caráter facultativo do alistamento e do voto.

Pode-se considerar que os primeiros tempos da República foram marcados pelo domínio político e administrativo das oligarquias regionais agrárias mercantis, cujas práticas políticas baseavam no coronelismo, nas fraudes eleitorais, etc. As elites políticas no nível federal representavam à política café com leite, uma vez que os representantes de Minas Gerais e de São Paulo revezavam-se na condução da política nacional. Portanto, federalismo brasileiro teve como característica fundamental a desigualdade entre os Estados, pois apenas três Estados tinham força política e econômica (São Paulo, Minas Gerais, e posteriormente Rio Grande do Sul). Além disso, nosso federalismo era baseado no poder patrimonial e oligárquico, dado que esses Estados possuíam as maiores rendas, o maior eleitorado (mesmo reduzido) e força política no Congresso.

\section{ELEITORES E ELEGíVEIS NA DÉCADA DE 1930: DO IMPULSO DE INSTITUCIONALIZAÇÃO DA PARTICIPAÇÃO ELEITORAL À SUSPENSÃ̃O DAS ELEIÇÕES}

No entanto, esse quadro foi alterado com as sucessivas crises do café, quando a elite necessitou de um governo centralizado. Essa ideologia intervencionis- ta teve sua realização a partir da Revolução de 1930, quando o governo centralizou o poder no Estado e administrou as unidades subnacionais, por meio das 
interventorias estaduais. 0 recurso à centralização se deu pela crítica ao federalismo oligárquico vigente até então, representado pela política dos governadores, pelo grupo do movimento de 1930.

A aliança liberal, que conduziu o processo de 1930, tinha como uma dos seus lemas, representação e justiça, ou seja, uma posição pela transparência das eleições e da administração pública. Assim, logo da instauração do governo provisório, presidido por Getúlio Vargas, foi designada um comissão para reformar o processo eleitoral, que resultou no código eleitoral de 1932 que foi utilizado nas eleições Constituintes de 1934.

A grande inovação do código de 1932 foi à extensão do direito ao voto às mulheres, sendo o Brasil o segundo país da América Latina a universalizar o sufrágio feminino, depois do Equador (1929). Desse modo, era eleitor, independentemente do sexo, os maiores de 18 anos. No entanto, assim como no período anterior, mendigos, analfabetos, praças de pré, a exceção dos estudantes das escolas militares de ensino superior, não podiam alistar-se. 0 voto era facultativo para as mulheres de qualquer idade e para os homens maiores de sessenta anos.

0 alistamento era feito por iniciativa do cidadão ou ex-officio, automaticamente. Este último era realizado pelos chefes de repartições públicas e de empresas que deveriam alistar seus funcionários. Essa vinculação com o funcionalismo público teve relação com a exigência de ser eleitor para exercer emprego público. Entretanto, em relação à qualificação dos votantes, a organização e o controle do processo eleitoral, a apuração dos votos e a diplomação dos eleitos, o código de 1932 inovou na criação da Justiça eleitoral, composta de um tribunal superior, de tribunais regionais e de juízes eleitorais. Desse modo, os municípios foram divididos em seções eleitorais com limite de 400 eleitores, que se encarregavam, após as eleições, de enviar as urnas lacradas pelo correio aos Tribunais Regionais eleitorais, aonde ocorria à apuração.
Aperfeiçoou-se o voto secreto com a introdução de um envelope (sobrecarga) oficial, padronizado, rubricada e assinada pela mesa eleitoral no qual as cédulas eram inseridas, assim como a determinação de um lugar fechado aonde o eleitor colocava a cédula na sobrecarga, além de, pela primeira vez, o título eleitoral apresentar foto e impressão digital dos eleitores. Com essas medidas, além de excluir a prática do bico de pena, "evitava-se a prática comum na Primeira República de os partidos utilizarem envelopes de cores, tamanhos e formatos diferentes para controlar o voto dos eleitores" (NICOLAU, 2004, p. 39).

Quanto à elegibilidade, o código de 1932 apresenta outra especificidade em relação aos anteriores: a exigência de registro prévio dos candidatos antes das eleições. Desse modo, se por um lado eram permitidos candidatos avulsos, por outro, grupos, Partidos, com pelos menos 100 mil eleitores tinham que registrar suas listas de candidatos no Tribunal Regional Eleitoral. 0 código, também, previa a eleição dos candidatos representantes de classes profissionais, que ocorriam de forma indireta, por meio de, num primeiro momento, eleição secreta e por maioria absoluta dos delegados pelos associados dos sindicados, e num segundo, os delegados elegiam os representantes classistas.

O sistema eleitoral adotado para as eleições para a câmara de Deputados (Constituinte de 1933, e Câmara de deputados 1934) foi misto, com aspectos do modelo proporcional e do majoritário. Nesse modelo a lista de candidatos era impressa, e podia-se, em ordem de preferência, votar em tantos nomes quanto fossem as cadeiras do Estado na Câmara, mais um (NICOLAU, 2004). A apuração privilegiava o cabeça da lista, ou seja, aquele mais votado em primeiro lugar nas listas eleitorais, que determinaria a votação total do partido. Da divisão do número de eleitores pelo número de cadeira determinava-se o quociente eleitoral, e cada Partido elegia um candidato a cada vez que atingisse o coeficiente eleitoral. Logo, na primeira etapa os candidatos mais votados em primeiro lugar na lista eram eleitos. Já na segunda, somavam-se o 
total de votos e os nomes mais votados, independente da ordem, ficavam com as cadeiras restantes.

Já os Senadores eram escolhidos de forma direta, majoritariamente, para as duas vagas estipulada para cada Estado da federação para um mandato de 8 anos. Assim, como na lei anterior, eram elegíveis os candidatos com mais de 35 anos, regra que se aplicava, também, aos candidatos à câmara dos deputados.

\section{ELEITORES E ELEGÍVEIS NA REDEMOCRATIZAÇ̃̃O DE 1945: REPRESENTAÇ̃̃O POLÍTICA PARTIDÁRIA E CRESCIMENTO ELEITORAL}

Com o fim do Estado Novo, em 1945, convocaram-se eleições para presidente, Senadores, e deputados para compor a Assembleia Nacional Constituinte. A lei eleitoral desse período de redemocratização foi a Agamenon (referência ao ministro da justiça que redigiu o decreto). Este decreto manteve os dois processos de alistamento da lei anterior, mas produziu resultados mais expressivos:

O alistamento feito em 1945 foi muito mais eficiente do que o realizado 12 anos antes (1933). Foram registrados 6,168 milhões de eleitores, um crescimento de $329 \%$ enquanto a população cresceu apenas $25 \%$ no período (NICOLAU, 2004, p. 43).

Uma das explicações para este fato foi à implantação da obrigatoriedade do voto. Na lei anterior tal artigo tinha sido implantado, mas como foi implantado poucos meses antes das eleições, o impacto sobre o alistamento eleitoral foi menor. Além disso, na legislação anterior a obrigatoriedade era restrita aos homens maiores de 18 anos e funcionários públicos, na Agamenon o alistamento e o voto eram obrigatórios para todos, homens e mulheres, prevendo multas para
O código eleitoral de 1932 vigorou para as eleições para a Constituinte de 1933 e para os pleitos seguintes para compor a Câmara de deputados. A constituição de 1934 manteve o texto da legislação eleitoral de 1932, embora não tenha sido realizada as eleições previstas para o executivo federal, dado que o código durou apenas até 1937, quando Getúlio Vargas instaurou o Estado Novo no Brasil, o qual proibiu o funcionamento dos Partidos Políticos, do Congresso Nacional e a realização de eleições. aqueles que não cumprissem suas obrigações eleitorais. Outra questão lembrada por Nicolau (2004) foi à utilização do alistamento ex-ofício pelos interventores estaduais e pelos sindicatos.

0 direito ao voto era estendido a todos maiores de 18 anos, excluindo-se os analfabetos, os militares na ativa, a exceção dos oficiais, os mendigos e aqueles com direitos políticos cassados. Portanto, embora tenha ocorrido o incremento no alistamento, como destacou-se acima, os eleitores representavam menos da metade da população apta a votar, uma vez que o censo registra na década de 1940 o número de analfabetos com mais de dez anos ultrapassava 55\% da população, e na década de 1950 esse número, para maiores de 15 anos, superava 50\%.

Um item pouco destacado na legislação eleitoral de 1945 é que as mulheres que exercessem profissões não lucrativas, assim como os inválidos, os maiores de 65 anos, os brasileiros a serviço do país no exterior, os oficiais em serviço militar, os servidores públicos em licença ou férias fora do 
domicílio, e os magistrados, não eram obrigados a votar. Portanto, embora o sufrágio fosse universal e obrigatório, para algumas frações sociais ou profissionais teve caráter facultativo.

Em relação à elegibilidade os Partidos Políticos passaram a ter centralidade no processo eleitoral, já que não era mais possível a existência de candidatos avulsos, nem da representação classista. A regulamentação dos Partidos passou a exigir o critério nacional, uma vez que era exigida assinatura de pelo menos 10 mil eleitores em, no mínimo, cinco Estados, para obter o registro. Esse número passou para $50 \mathrm{mil}$ eleitores em 1946.

Outra inovação foi à adoção de um sistema eleitoral estritamente proporcional nas eleições da câmara dos deputados. A partir de uma lista fornecida pelos Partidos ou coligação partidária o eleitor escolhia um único nome, não mais listando sua ordem de preferência. 0 partido conquistava tantas cadeiras quanto atingisse o quociente eleitoral (divisão do total de votos válidos pelo número de cadeiras disputadas). As cadeiras vagas ficavam com os Partidos mais votados em cada Estado. Portanto, a legislação de 1946 privilegiou os Partidos, em especial aqueles mais estruturados nacionalmente, como condutores da representação política Já as eleições para presidente e vice ocorriam em pleitos separados, pelo sistema majoritário de maioria simples, assim como as para Senadores, e para governadores.

Outra questão referente à elegibilidade é que o mesmo candidato poderia concorrer para vários cargos em diferentes Estados. Portanto, o candidato poderia ser eleito em cargos e Estados diversos, no mesmo pleito, cabendo a ele a escolha, tal como aconteceu com Getúlio Vargas, eleito deputado federal em sete Estados, e Senador no Rio Grande do Sul e São Paulo, que optou pela representação do Rio Grande do Sul, ajudando a eleger com seus votos diversos deputados federais do PTB.
Os estudos sobre esse período enfatizam o crescimento da participação eleitoral. Uma das razões desse incremento no eleitorado deve-se, de uma parte, ao incremento da população urbana, com o deslocamento das massas rurais para as áreas urbanas, ao desenvolvimento econômico e a incorporação do trabalhador ao Estado, e por outra, pelo próprio funcionamento das instituições implantadas para regularizar o processo eleitoral, como comenta Fabiano Santos (2007, p. 40):

\begin{abstract}
A República de 1946 significou mais do que a passagem para o sistema proporcional e as origens da nacionalização da vida partidária, conquistas que por si só já valeriam todo um regime. O Brasil, pós-Segunda Guerra, assistiu também ao início de um contínuo e impressionante processo de incorporação político-eleitoral. Se ao longo de toda republica velha o comparecimento eleitoral nunca ultrapassou a marca de $5 \%$ da população adulta, feito excepcional nas eleições presidenciais de 1930, já nas eleições de 1945 este mesmo indicador subiu para $13,4 \%$, chegando a $20 \%$ ao final do período com as eleições de 1962. Se juntarmos a estas informações a prevalência da representação proporcional, além da criação e atuação da justiça eleitoral, cuja finalidade foi a de garantir a lisura do pleito eleitoral e veracidade a seus resultados, então pode-se dizer que o período 1946-1964 caracterizou por uma verdadeira ruptura político-institucional no país
\end{abstract}

Cabe destacar que desse corpo eleitoral estavam excluídos os analfabetos, que, em 1945, representavam cerca de metade da população brasileira registrada nos censos. Tal estimativa apresentou uma redução até 1962, conforme quadro abaixo:

Quadro III: \% Analfabetismo da população brasileira (+ de 5 anos de idade)

\begin{tabular}{|l|l|l|l|l|}
\hline 1945 & 1950 & 1954 & 1958 & 1962 \\
\hline 54,3 & 51,6 & 45,5 & 45,5 & 35,7 \\
\hline
\end{tabular}

Fonte: SANTOS (2003, p. 65), IBGE

A lei eleitoral de 1950 apresentou poucas variações em relação à anterior. Aboliu o alistamento ex-officio e assim, todo brasileiro maior de 18 anos tinha por obrigação tirar seu título eleitoral no cartó- 
rio eleitoral. A partir de 1955 os eleitores só podiam votar em suas seções designadas, não podendo votar em qualquer outra seção do município. Assim como, nesta década, foram confeccionadas cédulas oficiais pela justiça eleitoral, evitando assim a distribuição de cédulas pelos Partidos Políticos.

Outra modificação refere-se à fórmula eleitoral para as eleições proporcionais, que é o mesmo modelo adotado até hoje, com algumas alterações, para as eleições para a Câmara dos Deputados. Sintetica- mente as cadeiras são divididas por aqueles Partidos que atingem o quociente eleitoral (divisão do total de votos válidos - composto dos votos dos partidos e dos votos em branco-pelo total de cadeiras). A cada vez que a soma dos votos do Partido atinge o coeficiente eleitoral conquista uma cadeira. Já as cadeiras restantes são distribuídas segundo o sistema de maiores médias, ou seja, os votos de cada partido são divididos pelo número de cadeiras que ele conquistou mais uma. Portanto, aqueles com maiores médias asseguravam as cadeiras restantes.

\section{ELEITORES E [NÃO) ELEGIVEIS DURANTE A DITADURA MILITAR DE 1964: VOTO DE PROTESTO E OS “CASUÍSMOS” ELEITORAIS}

Com a instituição da Ditadura Militar em 1964 nem todas as eleições diretas foram abolidas, como em outros regimes políticos autoritários. De modo geral pode-se considerar que todas as eleições a cargos majoritários foram abolidas, enquanto as eleições proporcionais coexistiram com o governo autoritário, a exceção de alguns períodos. 0 código eleitoral em vigor nesse período foi o de 1965, o qual se difere substancialmente das legislações anteriores. Uma delas, entre outras, refere-se à obrigatoriedade do eleitor em votar em candidatos do mesmo Partido para Deputado Federal e Estadual (voto vinculado), e a estipulação de multas significativas para aqueles que não se alistassem e nem justificassem o não comparecimento eleitoral. Desse modo: "Em que pesem a legislação eleitoral casuística e as restrições estabelecidas à competição partidária, durante o regime militar houve um contínuo crescimento do número de eleitores. Entre 1966 e 1982, o eleitorado cresceu 163\%." (NICOLAU, 2004, p. 60)

Esse incremento teve relação com as punições previstas em lei para aqueles que se alienassem dos compromissos eleitorais, tais como multa de $5 \%$ a três salários mínimos pelo não alistamento, de $5 \%$ a $20 \%$ do salário mínimo para o não comparecimento eleitoral sem justificativa, impedimento de obter passaporte, carteira de identidade, de inscrever-se em concurso público para aqueles que não tivessem se alistado, votado e justificado a ausência. Por outro lado, esse incremento na participação eleitoral, também, se refere ao aumento de votos nulos e brancos, uma espécie de voto de protesto ao sistema político, verificado em todo período autoritário.

A emenda Constitucional n. 15, de 19 de novembro de 1980, restabeleceu o voto direto nas eleições para Governadores de Estado, e embora tenha sido restituído o multipardarismo, uma série de dispositivos reduziu a atuação dos Partidos, o que não impediu que a maioria dos governos estaduais fossem conquistados pela oposição ao regime, enfraquecendo o regime militar. Portanto, o processo de liberalização, ou democratização no Brasil foi liderado pelos Barões da federação (ABRÚCIO, 1998). Importa destacar, a despeitos dos casuímos eleitorais desse período, que o ano de 1985 , marca a transição do regime, que é finalizada com a implementação da Constituição democrática de 1988. 


\section{ELEITORES E ELEGIVEIS A PARTIR DA CONSTITUIÇÃO DE 1988: DEMOCRATIZAÇ̃̃ DA PARTICIPAÇÃO ELEITORAL E DA REPRESENTAÇ̃̃O POLIITICA}

Com a promulgação da Constituição de 1988, "batizada" pelo então presidente da constituinte Ulysses Guimarães de "Constituição Cidadã", implantou-se as regras eleitorais em vigência até hoje, com algumas modificações. Neste momento, após cerca de cem anos, o direito ao voto foi estendido aos analfabetos, embora de caráter facultativo. Portanto, foi instituído o sufrágio universal obrigatório para todos brasileiros maiores de 18 anos, facultativo para os jovens de 16 até 18 anos, e para os maiores de 70 anos, além dos analfabetos.

Quanto à elegibilidade podem se candidatar todos aqueles que provem nacionalidade brasileira ou condição de português equiparado, que estejam em pleno exercício dos seus direitos políticos, que tenham domicilio eleitoral na circunscrição, pelos menos há um ano antes do pleito; que sejam filiados a algum Partido Político a pelo menos um ano antes das eleições; e possuir a idade mínima para o cargo concorrido até a data da posse. Em relação a este último aspecto para concorrer ao pleito para vereador exige-se maioridade de 18 anos; para prefeito, vice-prefeito, Deputado Estadual e Federal maioridade de 21 anos; Para governador e Vice-governador mais de 30 anos, e maio- ridade de 35 anos para concorrer à presidência e vice-presidência da república e para compor o Senado.

Em relação ao modelo eleitoral a modificação mais significativa refere-se às eleições majoritárias em dois turnos. Desse modo, nas eleições para prefeitos, governadores e presidente caso nenhum candidato conquiste maioria absoluta ( $50 \%$ mais 1 ) no primeiro turno, realiza-se novo turno entre os dois candidatos mais votados. Já nas eleições proporcionais, para os legislativos estaduais, nacional e câmaras municipais permitiu-se a coligação dos Partidos para obter o coeficiente eleitoral, mudaram-se as distribuição das cadeiras, uma vez que, a partir de 1998, os votos em branco deixaram de ser contabilizados para o cálculo do coeficiente eleitoral.

Uma das inovações, implantada a partir de 1996 foi à adoção de Urnas eletrônicas. De modo geral, o processo eletrônico facilitou a apuração das votações, e evita uma série de fraudes eleitorais, tais como as que ocorriam com a cédula escrita. No entanto, embora tenha aumentado o número de eleitores registrado desde a redemocratização o Brasil tem um dos maiores índices de votos nulos, o que sugere um contexto de crise da democracia eleitoral.

\section{CONSIDERAÇ̃̃ES FINAIS}

A análise histórica da cidadania política e da participação eleitoral no Brasil revela, entre avanços e recuos, um processo progressivo de inclusão da população na política, mesmo que de modo formal. 0 conhecimento deste processo histórico, ou o "longo caminho", como denominou José Murilo de Carvalho (2002), ajuda a percepção, não apenas das idiossincrasias do sistema eleitoral representativo implanta- 
do no Brasil, mas, também, de que a forma a cultura política foi moldada, apreendida pela população em distintos períodos históricos.

O conhecimento do processo de incorporação da população à política no Brasil possibilita, portanto, a partir da identificação dos padrões históricos, refletir sobre a história presente, do porque do descrédito das instituições políticas e do jogo representativo no Brasil. Desse modo, acredita-se que este esforço possa sugerir pistas para uma maior compreensão da história política brasileira e sobre seu devir histórico.

\section{REFERÊNCIAS}

ADORnO, S. Os Aprendizes do Poder. (O Bacharelismo Liberal Na Política Brasileira). Rio de Janeiro: Paz e Terra, 1998.

BRASIL, Tribunal Superior Eleitoral. Títulos eleitorais: 1881-2008: Brasília, TSE/SGI, 2009.

CAMARGO, Aspácia. Federalismo e identidade nacional. In: Sachs, Ignacyetalli (orgs). Brasil: um século de transformações. São Paulo: Companhia das letras, 2001.

CARVALHO, José Murilo de. Mandonismo, coronelismo, clientelismo: umadiscussãoconceitual. In: Dados, vol. 40, 2, Rio de Janeiro, 1997.

CARVALHO, José Murilo de. A construção da ordem: a elite política imperial. Rio de Janeiro: UFRJ, RelumeDumará, 2006.

CARVAlHO, José Murilo de. Cidadania no Brasil: o longo caminho. Rio de Janeiro: Civilização Brasileira, 2002.

COSTA, EmíliaViotti. Introdução ao estudo da emancipação política do Brasil. In:

MOTTA, Carlos Guilherme (Org.). Brasil em perspectiva. São Paulo: Difel, 1981.
FERREIRA, Manoel Rodrigues. A evolução do sistema eleitoral brasileiro. Brasília: TSE/SDI, 2006.

LEAL, Vitor Nunes. $\mathbf{0}$ coronelismo, enxada e voto: 0 município e o regime representativo no Brasil. São Paulo: Alfa-Ómega, 1975.

MARSHALL. T. H. Cidadania, classe social e status. Rio de Janeiro: Zahar, 1967.

NICOLAU, Jairo.História do Voto no Brasil. Rio de Janeiro: Jorge Zahar, 2004

REIS, Elisa. Processos e Escolhas. Rio de Janeiro: Contracapa, 1998.

SAES, Décio Azevedo Marques de. A questão da evolução da cidadania política no Brasil. Revista Estudos avançados, IEA/USP. São Paulo, vol. 15, n. 42, 2001.

SANTOS, Wanderley Guilherme. 0 cálculo do conflito. Estabilidade e crise na política brasileira. Belo Horizonte: UFMG; 2003.

SANTOS, Fabiano. A República de 46. Separação de poderes e política alocativa. In: MELO, Carlos Ranulfo. SÁEZ, Manoel de Alcântara. A Democracia brasileira. Balanço e perspectivas para o século 21. Belo Horizonte: UFMG, 2007. 
1 Mestre e Doutora em Ciência Política pela UFRGS. Professora Titular I do Núcleo de Pós-Graduação em Ciências Sociais da FITS, e Pesquisadora do Instituto de Tecnologia e Pesquisa (ITP). E-mail: lorena.madruga@gmail.com Aprovado em: 20 de Dezembro de 2013

2 Doutora e Mestre em Antropologia Social pela UNICAMP, Graduada em Ciências Sociais pela UNICAMP. Professora Titular II do Núcleo de Pós-Graduação em Ciências Sociais, FITS, Pesquisadora do Instituto de Tecnologia e Pesquisa (ITP). E-mail: danieladecarmo@gmail.com 